long way from being able to label any cigarette as less hazardous. That will be possible only when we have learnt enough about the basic mechanisms of the main smoking related diseases to be able to eliminate the causative factors from cigarette smoke.

TIM HIGENBOT'TAM

Consultant Physician and Director,

Department of Respiratory Physiology,

Papworth Hospital,

Cambridge CB3 8RE

1 Schuman L.M. The health consequences of smoking: a report of the Surgeon General. Rockville, Maryland: Public Health Service Office of Smoking and Health, 1981. (United States Department of Health and Human Services report No 20857.

2 Pierce JP. International comparisons of trends in cigarette smoking prevalence. Am f Public Health 1989;79:152-7.

3 Orleans CT. Understanding and promoting smoking cessation: overview and guidelines for physician intervention. Annual Review of Medicine 1985;36:51-61

t Hughes JR, Hatsukami D Signs and symptoms of tobacco withdrawal. Arch Gen Psychiury 1986:43:289-94.

5 Participants of the fourth Scarborough conference on preventative medicine. Is there a future for lower-tar-yield cigarettes? Lancet 1985 ;ii:1111-4.

6 Fairweather FA, Carmichael IA, Phillips CF. Changes in the tar, nicotine and carbon monoxide vields of cigarettes sold in the United Kingdom. Health Trends 1981;13:77-82.

7 Brunnemann KD, Hoffman D, Wynder EL, Gori GB. Determination of tar, nicotine and carbon monoxide in cigarette smoke. In: Wynder EL, Hoffman D, Gori GB, eds. Proceedings of third world conference on smoking and health. 1976:441-9. (DHEW publication $\mathrm{No}(\mathrm{NIH}) 76-1221$ ) New York.

8 Benowitz NC. Health and public policy implications of the "low yield" cigarette. N Engl J Med 1989;320:1619-21.

Gori GB, Lynch CJ. Analytical cigarette yields as predictors of smoke bioavailability. Regul Toxico Pharmacol 1985;5:314-26.

10 Lee PN, Garfinkel L. Mortality and type of cigarette smoked. $\mathcal{f}$ Epidemiol Community Health 1981;35:16-22.

11 Benowitz NL. Pharmacologic aspects of cigarette smoking and nicotine addiction. $N$ Engl f Med 1988:319:1318-30.

12 Young JC, Robinson JC, Rickert WS. How good are the numbers for cigarette tar at predicting deliveries of carbon monoxide, hydrogen cyanide and acrolein? 7 Toxicol Enziron Health $1981 ; 7: 801-8$

13 Benowitz NL, Jacob P, Yu L, Talcott R, Hall S, Jones RT. Reduced tar, nicotine and carbon monoxide exposure while smoking ultralow - but not low-yield cigarettes. FAMA 1986;256: 241-6.

14 Russell MAH, Jarvis MJ, Feyerband C, Saloojee Y. Reduction of tar, nicotine and carbon monoxide intake in low tar smokers. F Epidemiol Community Health 1986;40:80-5.

15 Lynch CJ, Benowitz NL. Spontaneous cigarette brand switching: consequences for nicotine and carbon monoxide exposure. Am f Public Health 1987;77:1191-4.

16 Maros DJ, Fortmann SP. Nicotine yield and measures of cigarette smoke exposure in a large population: are lower-yield cigarettes safer? Am f Public Health 1987;77:546-9.

17 Gori GB, Benowitz NL, Lynch CJ. Mouth versus deep airways absorptions of nicotine in cigarette smokers. Pharmacol Biochem Behav 1986;25:1181-4.

18 Sepkovic DW, Parker K, Axelrad CM, Haley NJ, Wynder EL. Cigarette smoking as a risk for cardiovascular disease. V. Biochemical parameters with increased and decreased nicotine content cigarettes. Addict Behav' 1984;9:255-63.

19 Higenbottam T, Shipley MJ, Rose G. Cigarettes, lung cancer, and coronary heart disease: the effects of inhalation and tar yield. $\mathcal{F}$ Epidemiol Community Health 1982;36:113-7.

20 Rimington $\mathrm{J}$. The effect of filters on the incidence of lung cancer in cigarette smokers. Environ Res $1981 ; 24: 162-6$.

21 Kaufman DW, Palmer JR, Rosenberg L, Stolley P, Warshauer E, Shapiro S. Tar content of cigarettes in relation to lung cancer. Am $\mathcal{F}$ Epidemiol 1989;129:703-11.

22 Doll R, Peto R. Mortality in relation to smoking: 20 years' observations on male British doctors. Br Med F 1976;ii:1525-36.

23 Augustine A, Harris RE, Wynder EL. Compensation as a risk factor for lung cancer in smokers who switch from nonfilter to filter cigarettes. Am f Public Health 1989;79:188-91.

24 Hammond EC, Garfinkel L, Seidman H, Lew EA. "Tar" and nicotine content of cigarette smoke in relation to death rates. Environ Res 1976;12:263-74.

25 Castelli WP, Garrison RJ, Dawber TR, McNamara PM, Feinleib M, Kannel WB. The filter cigarette and coronary heart disease: the Framington study. Lancet 1981;ii:109-13.

26 Rosenburg L, Kaufman DW, Helmrich SP, Shapiro S. The risk of myocardial infarction after quitting smoking in men under 55 years of age. N Engl f Med 1985;313:1511-4.

27 Kaufman DW, Helmrich SP, Rosenberg L, Miettinen OS, Shapiro S. Nicotine and carbon monoxide content of cigarette smoke and the risk of myocardial infarction in young men. $N$ Engl F Med 1983;308:409-13.

28 Palmer JR, Rosenberg L, Shapiro S. "Low yield" cigarettes and the risk of nonfatal myocardial infarction in women. N Engl f Med 1989;320:1569-73.

29 Borland C, Chamberlain A, Higenbottam T, Shipley M, Rose G. Carbon monoxide yield of cigarettes and its relation to cardiorespiratory disease. Br Med f 1983;287:1583-6.

30 Higenbottam T, Clark TJH, Shipley MJ, Rose G. Lung function and symptoms of cigarette smokers related to tar yield and number of cigarettes smoked. Lancet 1981:i:409-12.

31 Lee PN. Low tar cigarette smoking. Lancet 1980;i:1365-6.

32 Sparrow D, Stefas T, Bosse R, Weiss ST. The relationship of tar content to decline in pulmonary function in cigarette smokers. Am Rev Respir Dis 1983;127:56-8.

\title{
Women victims of domestic violence
}

\section{Treatment should extend beyond the obvious physical trauma}

Women's health is seen by many as screening for cervical and breast cancer or the provision of hormone replacement therapy. ${ }^{1}$ Others have provided a much wider perspective: the Australian government has published its national women's health policy, which embodies the World Health Organisation's definition of health as a state of complete physical, mental, and social wellbeing and not merely the absence of disease and infirmity. Violence against women is identified as a priority along with reproductive health and sexuality, health of aging women, women's emotional and mental health, occupational health and safety, and the health needs of women as carers. ${ }^{2}$

The extent of domestic violence-the preferred term according to a recently published report - remains unknown. That review states that violence is infrequently reported to the police and that in the absence of large population studies only estimates can be given. ${ }^{3}$ One such estimate is that each year half a million women are victims of domestic violence in England and Wales. ${ }^{+}$Some kind of physical violence has been said to occur in $20-30 \%$ of marriages ${ }^{5}$ whereas other studies have concluded that serious violence occurs in $1 \%^{6}$ to $5 \%^{7}$ of marriages in Britain. Over $90 \%$ of victims are women. Even at the lowest estimate domestic violence affects the health of many women.

Many victims of domestic violence consult their doctors because of their injuries. The presenting complaint may be obviously related to violence-physical injury or depression - or be more obscure, such as pelvic pain following sexual abuse. ${ }^{8}$ In one study, though $80 \%$ of women victims were examined by doctors, only a quarter disclosed that they had been beaten. ${ }^{9}$ Many more hinted at an underlying problem, but the doctors confined themselves to treating the physical injury.

Doctors can, however, play a crucial part in helping victims by being aware that domestic violence occurs and by being prepared to ask key questions. ${ }^{10}$ Information leaflets, such as those produced by Women's Aid, should be readily available in outpatient and casualty departments as well as in general practitioners' surgeries. In the United States the American College of Obstetricians and Gynecologists has taken the lead by producing a leaflet The Abused Woman ${ }^{11}$ as part of its Women's Health series, which defines the problem and gives practical help about escaping from an abusive relationship and obtaining legal advice. Doctors should also be well informed about sources of help such as Women's Aid, social work departments, and community units and be prepared to refer women to these agencies. They should also keep accurate records of injuries sustained - not least for medicolegal purposes. As students they need to be taught in detail about the scale, forms, and consequences of domestic violence. No information is available about whether such teaching is included in the undergraduate training in Britain. In the United States a recent study to determine the curriculum content of adult domestic violence in 143 accredited United States and Canadian medical schools found that no instruction was provided in just over half of the 117 schools that responded. The others provided an average of 1.5 sessions lasting 1.9 hours. ${ }^{12}$ New Jersey Medical School has taken the lead and has produced suggested hospital protocols and a training manual for health educators. ${ }^{13}$

An excellent review of domestic violence produced by the Home Office Planning Unit points out that an effective 
response requires more than treating injuries. ${ }^{3}$ Yet this does not happen partly because of "attitudes and beliefs about the 'proper' roles for men and women in relationships." These attitudes are ubiquitous and are held by the professionals who meet the victims of domestic violence. Progress will be made only when doctors not only deal with the immediate needs of victims but are also prepared to tackle the difficult task of looking for long term measures aimed at preventing domestic violence. That means identifying and then changing the conditions that give rise to it.

GILLIAN MCILWAINE

Community Medicine Specialist (Women's Health),

Glasgow Royal Maternity Hospital,

Glasgow G4 0NA

1 Department of Health. Promoting women's health. London: King's Fund, 1989. (Conference report.)
2 Commonwealth Department of Community Services and Health. National women's health policy advancing women's health in Australia. Canberra: Australian Government Publishing Service, 1989.

3 Smith LJF. Domestic violence: an overview of the literature. London: HMSO, 1989. (Home Office Research Study No 107. .

4 Freeman MDA. Violence in the home. Farnsborough: Sexon House, 1979.

5 Borkowski M, Mutch M, Walker V. Marital violence. The community response. London: Tavistock Publications, 1983.

6 Marsden D, Owen D. Jekyll and Hyde marriages. New Society 19758 May:333.

Marsden D. Sociological perspectives on family violence. In: Martin JP, ed. Violence in the family. Chichester: John Wiley, 1978

8 Harrop-Griffiths J, Kenton W, Walker E, Holm L, Russo J, Hickok L. The association between chronic pelvic pain, psychiatric diagnosis and childhood sexual abuse. Obstet Gynecol 1988;71: 589-94.

9 Dobash RE, Dobash RP. Violence against wives. New York: Free Press, 1979.

10 Schei B. Interviewing women about sexual abuse - experience from a controlled study of women in abusive relationships. In: Von Hall E, Everaerd W, eds. The free woman. Women's health in the abusive relationships. In: Von Hall E, Everaerd W, eds. The free woman.
1990s. Carnforth, Lancashire: Parthenon Publishing Group, 1989:726-33.

11 American College of Obstetricians and Gynecologists Patient Education. The abused woman. Washington, DC: ACOG, 1988

12 Centers for Disease Control. Education about adult domestic violence in US and Canadian medical schools 1987-88. FAMA 1989;261:972-8.

3 Braham R, Furniss K, Holtz H. Hospital training on domestic violence. Morriston, New Jersey: Jersey Battered Women's Service, 1986.

\title{
Training for general practice
}

\author{
No place for a national curriculum
}

Planning the education of future general practitioners has to take account of many influences. The government has called for improved undergraduate and vocational training and it is demanding some form of accountability. ${ }^{12}$ The profession wants a different form of audit ${ }^{34}$ and has new ideas on what constitutes the knowledge base of medicine generally ${ }^{5}$ and of primary care in particular. ${ }^{467}$ The European Community Commission requires that by 1995 general practitioners of all member states should have completed vocational training ${ }^{8-12}$ - and one consequence may be increased immigration from medically overcrowded neighbouring countries.

At present in Britain the quality of vocational training is very variable, as was highlighted in the furore ${ }^{1314}$ after the Joint Committee on Postgraduate Thinking in General Practice withdrew recognition of the North East Thames vocational training scheme in $1988 .{ }^{15} 16$ The content is also varied: some training puts less emphasis on chronic disease, ${ }^{17}$ management and communication skills, ${ }^{11}$ and palliative care ${ }^{18}$ than on acute conditions and specialties such as dermatology (M H Kelly, T S Murray, personal communication). Some commentators have argued that three years is not long enough for adequate training ${ }^{11}$; others seem satisfied.

In the current climate of opinion such variation is unsettling for planners. One solution that has been proposed is to agree a national curriculum, perhaps built upon The Future General Practitioner ${ }^{19}$ and the examination for the membership of the Royal College of General Practitioners, already seen by many as a test of satisfactory vocational training. Such a curriculum may be superficially attractive and seem a road to consensus, but consensus often means a compromise that suits nobody and one which may stultify the education process by the dullness of uniformity.

What young general practitioners need is teachers who know the difference between training, which fills the knowledge pot, and education, which lights the fire under it, and who will allow learners to develop the skills of communication and empathy so undervalued in present training ${ }^{20}$ and practice. $^{21}$ Young men and women are entering general practice from a wide range of backgrounds, races, cultures, medical schools, and life experience. ${ }^{22}$ Soon these differences may be swelled by imports from Europe. ${ }^{81012}$ How could a common curriculum be devised for so diverse a group of graduates?
To make sense of educating this highly disparate group we must think not of where we are trying to go but where we are starting from. Any curriculum laid down in advance might easily result in new graduates being taught what they already know while leaving many aspects of ignorance untouched. We need to test trainees before they start their vocational training, to measure the needs of entrants so that individual teaching may be offered to every trainee. General practice, with its unique opportunities for one to one teaching, is the only place where individual curricula could work: but that assumes that individual need would be accurately assessed at the outset of what may have to be a longer course. If the present rate of 25 applicants for each place increases then a pretest may also offer a useful method of selecting trainees.

Macmillan Senior Lecturer in Palliative Care,

ROBIN HULL

Department of General Practice,

University of Birmingham Medical School,

Birmingham B15 2TJ

1 Hull R. Government proposals for primary care: white hope, elephant, or sepulchre? Br Med $\mathcal{F}$ 1987;295:1436.

2 Secretaries of State for Social Services, Wales, Northern Ireland, and Scotland. Promoting better health. London: HMSO, 1987. (Cmnd 249.)

3 Pendleton D, Schofield T, Marinker M. In pursuit of quality. London: Royal College of General Practitioners, 1986.

4 Hart JT. A new kind of doctor. London: Merlin Press, 1988.

5 White KL. The task of medicine: dialogue at Wickenburg. Menlo Park, California: Henry J Kaiser Family Foundation, 1986

6 Stott NCH. Primary health care. Berlin: Springer Verlag, 1983.

7 Hull FM. The role of socio-behavioural scientists in health care practice. Soc Sci Med 1987;25: 679-87.

8 Hull R. Training for general practice in Europe. Horizons 1989;3:212-20.

9 Anor ymous. Assessment of vocational training [Editorial]. Fam Pract 1988;5:1-3.

10 Rombauts WAJA. A European perspective on postgraduate education. Biochem Soc Trans 1988;16:122-5.

11 Hasler JC. History of vocational training for general practice: the 1970s and 1980s. $\mathcal{F}$ R Coll Gen Pract 1989;39:338-41.

12 Horder J. Vocational training for general practice in the European community. $7 R$ Coll Gen Pract 1988;38:341-2.

13 Campkin N, Grant $\mathrm{D}$, Suckling $\mathrm{H}$. Withdrawing recognition for vocational training. $\mathrm{Br} \mathrm{Med} \mathcal{f}$ $1988 ; 296: 1331$

14 Josse SE. Vocational training in general practice. $\operatorname{Br} M e d f$ 1988;297:134

15 Lowry $S$. Vocational training in general practice: is action against north east Thames justified? BrMed f 1988;296:1320.

16 Anonymous. College action in the north east Thames region. $f$ R Coll Gen Pract 1988;38:239.

17 Hasler JC. Do trainees see patients with chronic illness? Br Med f 1983;287:1679-82.

18 Richards CM. The teaching of terminal care and care of the bereaved in vocational training schemes. RCGP/Schering scholarship report. London: Royal College of General Practitioners, 1987.

19 Royal College of General Practitioners Working Party. The future general practitioner. Learning and teaching. London: British Medical Journal, 1972.

20 Pickering G. Quest for excellence in medical education. London: Nuffield Provincial Hospital Trust, 1978.

21 Shorter E. Bedside manners, the troubled history of doctors and patients. New York: Simon and Schuster, 1985.

22 Payer L. Medicine and culture. London: Gollancz, 1989. 